\title{
New Table and Wine Grape Cultivars: World Scenario with Emphasis on Brazil
}

\author{
U.A. Camargo and P.S. Ritschel \\ Embrapa \\ National Research Center for Grape and Wine \\ Bento Gonçalves, RS \\ Brazil
}

Keywords: grape breeding, resistant varieties, Brazilian grapes, juice grapes, grape rootstock

\begin{abstract}
Viticulture is a millennia-old activity, traditional in many countries in Asia Minor and in Mediterranean Europe. The number of used cultivars is very large. Usually every region possesses its specific cultivars, selected over the centuries, which gave rise to typical regional products. Beginning in the $\mathrm{XIX}^{\text {th }}$ century, however, new wine growing countries appeared, and in the old, traditional ones, diseases and pests were introduced triggering the beginning of genetic breeding programs. In our days, genetic breeding of the grape is an important tool to make viticulture possible in traditional wine growing countries as well as in the new, emerging grape growers. New quality concepts in terms of human health and environmental protection, as well as the permanent changes of people's consumption habits show that technological innovation is paramount to ensure competitiveness of grape growers in traditional and emerging regions alike. Cultivars bear particular importance in this respect. This paper reports on general strategies of genetic grape breeding and presents new cultivar of table grapes and grapes for processing, with emphasis on the scenario in Brazil.
\end{abstract}

\section{INTRODUCTION}

The grapevine belongs to the genus Vitis, family Vitaceae. The genus Vitis consists of two sections, Euvitis $(2 n=38)$ with over 60 species and Muscardinia $(2 n=$ 40 ), with three species. It occurs naturally in climates as cold as Siberia and Canada, as well as in tropical regions such as Indonesia and the Caribbean. This occurrence in a wide range of climates displays the great genetic natural variability of the grapevine, making easier important improvements in genetic breeding through crossing. Viticulture is a millenia-old activity, especially in countries of Asia Minor and the Mediterranean coast of Europe, where a large number of old cultivars occur which have accumulated intravarietal genetic variations as a consequence of mutations that happened over the centuries. Clonal selection is an important grape breeding method.

Genetic breeding of grapes through crosses became important from the second half of the XIX ${ }^{\text {th }}$ century with the carrying out of interspecific crosses to obtain Phylloxera-resistant rootstocks. This root pest, which had been taken to Europe on American grapevines, led to the death of a large part of vineyards of Vitis vinifera, which is susceptible to it and was grown on its own roots at that time. Resistant rootstocks, then developed, allowed the continuity of the $V$. vinifera cultivation. Also at that time, many interspecific hybrid cultivars, additionally resistant to diseases caused by fungi, especially downy mildew (Plasmopara viticola) and powdery mildew (Uncinula necator) made possible the continuing grape growing activity in Europe in subsequent years. In the middle of the $\mathrm{XX}^{\text {th }}$ century, however, with the appearance of fungicides for the efficient control of fungal diseases and under the argument of the low quality of wines made of hybrid cultivars, the use of these cultivars in Europe was prohibited. Therefore, sexual breeding of the grapevine retained its relevance especially for table grapes, but lost it for wine grapes. On the other hand, great emphasis was put on the breeding of traditional European wine cultivars through clonal selection. In recent years, the concept of quality 
was extended to consider also human health, food safety and environmental protection. With this perspective and considering the large number of diseases and pests which attack the grapevine, planting of pest- and disease-resistant cultivars will become more relevant.

Despite the importance attributed to modern biotechnological processes, especially the genetic transformation, the classical process of breeding by hybridization and selection still remains the main method to obtain new cultivars in our days. This method allows obtaining new cultivars, combining several wanted features such as adaptation to specific environments, productivity, resistance to pests and diseases, quality compatible with requirements of different viticultural purposes and their respective market segments; however, it is relevant to underline those biotechnological tools may contribute significantly when associated with conventional breeding. This association includes the improvement of methods to obtain new materials (rescue and embryo culturing) as well as to improve the selection (molecular marker assisted selection) of new cultivars. Besides, genetic transformation, introducing genes of interest in cultivars of high market and cultural value, possesses perspectives of intense utilization, when its present wide use with other plant species.

\section{GRAPEVINE BREEDING: OBJECTIVES AND STRATEGIES}

Grape breeding to obtain new cultivars for table, wine, juice and raisins as well as rootstocks has been traditionally carried out by countries such as the United States, Germany, France, Hungary, South Africa, Australia and Brazil, among others. The objectives of these programs may, generally, be summarized as attempts to obtain cultivars adapted to the environmental conditions of specific regions, featuring high yields, resistance to diseases and pests, and quality fitting market requirements, including the functional properties of table grapes, wine and juice. It can be stated that the breeding programs aim at new higher quality cultivars, with lower production costs, to support the competitiveness of the products.

Genetic breeding is one of the most important methods to achieve competitiveness of viticultural products in the world market. The viticulture, until recently highly linked to traditions, begins to absorb technological innovations. The availability of new cultivars has revealed itself as indispensable for competitiveness. In the table grape segment, seedless grapes conquer larger market spaces and new seedless cultivars compete with traditional ones (Lorenzo, 2003). New juice grape cultivars, with shorter phenologic cycles, higher glucometric potential and adapted to tropical climates point to a progressive and increasing substitution of traditional cultivars for juice production in Brazil. Even regarding wine, a product strongly associated with tradition, technological advancements have triggered significant changes. The growing concern of consumers with health and the environment are increasing the demand of wines produced with a minimum of or without the use of chemicals, fostering the use of new, disease-resistant cultivars (Christmann, 2005). In this respect, Germany and Hungary stand out with increasing areas planted with new interspecific hybrid varieties for the production of wine under organic systems.

Patent and intellectual property laws have been adopted by the majority of countries that carry out breeding programs. They assure the owner or obtainers of the cultivars the property rights, requiring from users of the new cultivars the licensing and royalty payment. This has stimulated a growing involvement of private companies and a withdrawal of the public sector from grapevine breeding programs. New introduced cultivars may not present the expected adaptation or a satisfactory performance in regions with different climates from those where the cultivars have been developed. Therefore the availability of own, adapted cultivars is a fundamental factor of independence of every grapevine growing region.

\section{NEW CULTIVARS: THE WORLD SCENARIO}

The grapevine is a traditional crop. Some cultivars such as 'Syrah', 'Cabernet Sauvignon', 'Sultanine', 'Concord' and many others have been cultivated for centuries or 
even are millenary. Innovation of cultivars of grapes for wine has been more difficult due to the existence of a strong association of the types of wines of the main growing regions of Europe with their regional cultivars and the terroir. In the new wine growing countries, the production of varietal wines predominates, taking advantage of the established image of the cultivars of traditional wine regions such as 'Riesling', 'Chardonnay', 'Cabernet Sauvignon', 'Merlot' and others, which are a reference for many consumers; however, some new cultivars of wine grapes are beginning to develop their own image, e.g., the cultivar 'Pinotage', in South Africa. With table grapes innovation takes place more easily and the spread of new cultivars is more frequent. Good examples, along the time, are the cultivars 'Italia', 'Cardinal', 'Red Globe', 'Victoria', 'Perlette', 'Flame Seedless', 'Sugraone' and 'Crimson Seedless', among others. There has been smaller innovation in the spectrum of grape varieties for juice. With rootstocks, traditional cultivars such as 'SO4', '1103 P', '420 A' and '3309 C' predominate in most wine growing regions. Presently, however, consumption habits have changed quite rapidly and mass communication media promote new products easily. New quality concepts putting emphasis on human health, environmental protection and the price lead to innovation and the substitution of traditional cultivars by new, more competitive ones in terms of price and quality.

In Table 1, a relation of cultivars released by several breeding programs is presented, as well as their respective sources for further information. Most recently released cultivars of table grapes are seedless, in a clear attempt to fit market tendencies. Besides seedlessness other features have been determinant for their release: precocity, quality (sugar content, balanced taste, crunchy texture), size and color of the berry, postharvest storage and shelf life (resistance to berry drop and cold storage), low production cost (high yielding, low labor intensity) and resistance to diseases. With respect to table grapes, there are outstanding breeding programs such as those of the Agriculture Research Service (ARS)/USDA and the University of California (United States), the Volcani Center (Israel) and the Agricultural Research Center (South Africa). In Hungary, the Research Institute for Viticulture and Enology of the Agricultural Ministry has recently released new disease-resistant table grape cultivars. The Institute for Grapevine Breeding Geilweilerhof (Germany) stands out for the number of released interspecific, hybrid wine cultivars, which are resistant to downy mildew and powdery mildew. These cultivars build the fundamental support for the German organic wine industry. Cornell University has launched new hybrid cultivars which are cold- and Phylloxera-resistant, and tolerant to some diseases, while the CSIRO Plant Industry, in Australia, and the Volcani Center, in Israel, are leading in Vitis vinifera breeding, having released, respectively three and one new cultivar(s) for wine adapted to hot climates. Little has been done in genetic breeding of new grape varieties for juice. In the considered period, only the University of Arkansas launched one variety for that purpose. New rootstocks with nematode-resistance associated with the induction of higher grape quality for wine have been obtained in United States by ARS/USDA.

\section{BREEDING AND NEW GRAPEVINE VARIETIES IN BRAZIL}

Grapevine breeding in Brazil began at the Instituto Agronômico de Campinas (IAC), in 1943, with the aim of developing new cultivars of rootstocks, for table grapes, raisins, wine and juice adapted to the conditions of Brazil. This program succeeded in launching several cultivars, such as the rootstocks 'IAC 313', 'IAC 572' and 'IAC 766', all of which stem from tropical species, which are perfectly adapted to Brazilian tropical climate.

In 1977, the Embrapa/National Research Center for Grape and Wine started a grapevine breeding program to develop new wine cultivars. Later the objectives of the program were expanded to cover table grapes and grapes for juice and more recently rootstocks too.

More specifically the program has the objective of creating new cultivars which support the competitiveness and sustainability of the Brazilian viticulture, are adapted to 
hot climates, are high yielding, pest- and disease-resistant and have low labor intensity. Additionally, they must allow mechanic cultivation and fit quality attributes coherent with market tendencies. In this program, a wide genetic base is used which consists of cultivars of Vitis vinifera and Vitis labrusca, several other Vitis species and many interspecific hybrids (Camargo, 2000). Depending on the purpose grapevines are bred for the following objectives: a) table grapes - seedless cultivars, with the necessary qualitative diversity concerning taste, color, shape and texture to comply with the demands of the internal and external market; b) grapes for wine - cultivars with typical aroma and taste, low production costs to supply the internal market; c) juice - cultivars with labrusca-type features of color, aroma and taste and high sugar content, allowing higher industrial output; d) rootstocks - cultivars with resistance to Eurhizococcus brasiliensis, a root pest, native to southern Brazil, which causes decline and death of vineyards.

The main utilized breeding method is hybridization and selection associated with biotechnology techniques such as embryo rescue and cultivation and molecular markers assisted selection for seedlessness. Segregating populations are used for genetic studies such as the identification of molecular markers and resistance genes to downy mildew and powdery mildew (Lima et al., 2002). Protocols for regeneration through somatic embryogenesis have been established and studies on genetic transformation are being carried out. As a tool for selection a protocol has been adjusted that allows the reduction of the juvenile phase of seedlings using the technique of Huglin and Julliard (1964), making the first selection possible in less than 24 months after carrying out the crosses (Camargo et al., 2003). With two plant development cycles/year, the second selection can be concluded in the two subsequent years and the final evaluation may be made in several regions with tropical conditions. This offers enough repeatability in around two years, allowing the release of new cultivars seven to eight years after carrying out the crosses. This model, given the fastness of the selection process, makes it possible to evaluate large numbers of seedlings in relatively small areas. Concerning to cultivars of Vitis labrusca, traditionally cultivated extensively in vineyards in southern Brazil, possessing important intravarietal variability, the classical method of clonal selection is used.

From 1994 through 2004, Embrapa/National Research Center for Grape and Wine has released nine new cultivars and two clones, as detailed below.

\section{Table Grapes}

The breeding of table grapes aims at two types of grapes: a) labrusca-type grapes which possess the characteristic, specific taste and the fruit flesh which detaches itself from the berry skin under pressure; it is highly appreciated by Brazilian consumers; and b) vinifera-type grapes, with a firm flesh. From the first group the cultivars 'Dona Zilá' and 'Tardia de Caxias', from the second one the cultivars 'BRS Clara', 'BRS Linda' and 'BRS Morena' have been released.

1. 'Dona Zilá'. It is a Vitis labrusca cultivar, derived from the cross of 'Niagara Branca' $\times$ 'Catawba Rosada', launched in 1994. Maturation is late, approximately 45 days after 'Niágara Rosada'; it is recommended for regions of higher altitude in southern Brazil, as a strategy for expanding the production period and the grape supply in the region. The bunch is medium-sized, 200-250 g and compact. The berry is rose, spherical, $19 \mathrm{~mm}$ in diameter; the fruit flesh is typical labrusca, sweet, $17^{\circ}$ Brix, low acidity, good labruscataste. It is tolerant to downy mildew and resistant to powdery mildew, but susceptible to anthracnose (Elsinoe ampelina). This cultivar is a good option for Rio Grande do Sul and Santa Catarina states.

2. 'Tardia de Caxias'. This is a rustic table grape variety, selected from a cross of 'Niagara Branca' × 'Catawba Rosa' and launched in 1994. The bunch is medium-sized, 250-300 g and compact; berries are light rose, $20 \mathrm{~mm}$ in diameter, spherical, fruit flesh typical labrusca, $15^{\circ}$ Brix, low acidity, 40 to $50 \mathrm{meq} / \mathrm{L}$, mild labrusca-taste. It shows the same general features of the cultivar 'Dona Zilá' and represent another choice for delaying the harvest in regions of higher altitude in southern Brazil.

3. 'BRS Clara'. Seedless grape cultivar launched in 2003 for growing in tropical regions. 
Obtained from a cross of 'CNPUV 154-147' $\times$ 'Centennial Seedless'. It is characterized by high natural fertility and high yields (25-30 t/ha) and high sugar potential, easily reaching $20^{\circ}$ Brix. The bunches are large, 400-500 g, naturally loose, generally making berry thinning unnecessary. The berries possess a crunchy texture, a mild muscat-flavor, and yellow color, reaching $17 \mathrm{~mm}$ diameter using giberellic acid. Its behavior in relation to fungal diseases is similar to that of the cultivar 'Italia'; however, it is tolerant to bacterial canker (Xanthomonas campestris pv. viticola). The cultivar meets widely acceptance in the main table grape producing belts as well as on the Brazilian market. This is a protected cultivar.

4. 'BRS Linda'. This is a cultivar of white seedless grapes for tropical climates in Brazil, released in 2003. It was selected from the crossing of 'CNPUV 154-90' × 'Saturn'. It is highly productive and yields 30 to $35 \mathrm{t} / \mathrm{ha}$ of high quality grapes. The bunch is large, weighs 700 to $800 \mathrm{~g}$; it is naturally loose, thinning out of berries is not necessary. The berry is large, reaching $22 \mathrm{~mm}$ diameter when giberellic acid is used. It has a crunchy texture, neutral taste and greenish color. The sugar content is low, 14 to $15^{\circ}$ Brix, however, the taste is pleasant due to low acidity; it can be considered a light grape. It has high resistance to berry drop as well as an excellent post-harvest storage. Concerning to fungal diseases it behaves similarly to the cultivar 'Italia', but is more susceptible to powdery mildew. It is a protected cultivar.

5. 'BRS Morena'. Black seedless grape cultivar was launched in 2003 for the tropical conditions in Brazil. It was selected from the crossing of 'Marroo Seedless' $\times$ 'Centennial Seedless'. It is highly fertile, yields 20 to $25 \mathrm{t} / \mathrm{ha}$. The bunches weigh 40 to $500 \mathrm{~g}$ and are normally quite loose and need appropriate management for adequate berry set. The berry reaches a diameter of $20 \mathrm{~mm}$ with the use of AG3; it has a crunchy texture and a pleasant taste with 18 to $19^{\circ}$ Brix. Adequate packaging is required since berries are easily detached from pedicels. The cultivar is well accepted on the Brazilian market. Its behavior in respect to fungal diseases is similar to that of the cultivar 'Italia'. This cultivar is protected.

\section{Grapes for Wine}

More than $85 \%$ of the Brazilian wines are table wines made of American grapes and their hybrids. The main appeal to the consumers is their characteristics of aroma and taste and their reasonable prices. The breeding program of grapes for wine aims at developing new cultivars which are resistant to diseases, high yielding and make it possible to produce wines featuring the typical aroma, taste and low production costs. Two cultivars have been launched.

1. 'Moscato Embrapa'. It has been developed from the crossing of 'Couderc 13' $\times$ 'July Muscat' and was released in 1997 as an alternative grape for the production of an aromatic white table wine. This white grape cultivar is vigorous and resistant to fungal diseases, especially to bunch rot. Its productivity is high and it may yield more than 40 t/ha. It is, however, recommended to limit its production to $35 \mathrm{t} / \mathrm{ha}$ in order to ensure adequate ripening and the wanted qualitative level. It has good sugar potential, normally reaching $19^{\circ}$ Brix. The cultivar behaves well in the colder zones as well as in the tropical regions of Brazil; its maturation is late. The wine tastes slightly muscat with low acidity, thus being well accepted by the Brazilian consumers.

2. 'BRS Lorena'. Resulting from the crossing of 'Malvasia Bianca' $\times$ 'Seyval', this cultivar was released in 2001. It is especially recommended for processing into sparkling wine of the muscat-type. It yields $30 \mathrm{t} / \mathrm{ha}$; the sugar content is above $20{ }^{\circ} \mathrm{Brix}$ and the acidity is around 90 to $100 \mathrm{meq} / \mathrm{L}$. It is quite resistant to fungal diseases, especially to bunch rots, however, in certain years; its susceptibility to Phylloxera on the leaves requires the control of this pest. This cultivar is used to make typical sweet or dry muscat wines and sparkling wines with intense foam and persistent perlage. It is well adapted to temperate and tropical climates. 


\section{Grapes for Juice}

The production of grape juice in Brazil is based on Vitis labrusca cultivars and is concentrated in regions of temperate climate of the South; however, there exist perspectives of a significant evolution in the tropical regions of the country, as well. The selection of new cultivars and clones aims at expanding the harvest period in the south, with cultivars of different levels of precocity. It also has the objective to make grape production possible in tropical zones, with the use of cultivars which are adapted to hot climates. Two new cultivars and two clones have already been made available for the wine growers.

1. 'BRS Rúbea'. It is a red grape, developed from the crossing of 'Niagara Rosada' $x$ 'Ives Seedling'. It was released in 1999 and it is especially recommended to be mixed with 'Isabel' and 'Concord' grapes for juice production. It can also be used for table wine. The bunch is small, weighing on average $100 \mathrm{~g}$; the size of the berry is $19 \mathrm{~mm}$ in diameter and the sugar potential is $15^{\circ} \mathrm{Brix}$. As a main quality it features an intense coloration of the must which contributes to the enhancement of wines and juices made of other grapes. The cultivar is vigorous and resistant to diseases and well adapted to the conditions in the south of Brazil. It yields around $20 \mathrm{t} / \mathrm{ha}$ and does not behave well in hot climates, where it shows low vigor; nevertheless, it has been grown in Goiás state, with relative success, as an alternative to the "coloring" grape.

2. 'Concord Clone 30'. This clone was identified in 1989, through the Program for Genetic and Sanitary Clonal Selection of the Cultivar 'Concord'. After evaluated, it has been propagated due to its precocity; its maturity is reached 15 days in relation to the original cultivar. It presents the general characteristics of 'Concord' and was released in 2000. This cultivar is especially indicated as an alternative to early harvest and extends the production period and the process of making grape juice. It is recommended for the regions of temperate climate of South Brazil.

3. 'Isabel Precoce'. A spontaneous somatic mutation of the cultivar 'Isabel', it was identified and selected thorough the genetic clonal selection program of Embrapa. It presents the general characteristics of the original form; however, its maturation occurs about 35 days earlier. It represents an important alternative in order to extend the harvest period in the southern region. It has an excellent performance in hot regions and achieves positive results concerning yield and quality in Northeast São Paulo, in the Midwest (States of Mato Grosso and Goiás) and in the Submédio São Francisco Valley (states of Bahia and Pernambuco). The maturation of the grape is uniform, it does not display green berries on ripe bunches, a feature of the cultivar 'Isabel'. It is also processed into table wine.

4. 'BRS Cora'. This cultivar was developed from the crossing of 'Muscat Belly A' $\times$ 'BRS Rúbea'. It presents high productivity and an elevated sugar potential, 18 to 20 ${ }^{\circ}$ Brix. The must is strongly colored. Its vigor is moderate, with limited growth of the shoots. It was released in 2004 as an alternative cultivar for juice production and table wine making in tropical regions, to enhance the color of the products obtained from grapes of the cultivar 'Isabel' and 'Isabel Precoce'. It is well adapted to the temperate climate conditions in southern Brazil. This cultivar is protected.

\section{Literature Cited}

Camargo, U.A. 2000. Grape breeding for the subtropical and tropical regions of Brazil. Acta Hort. 528:473-477.

Camargo, U.A., Maia, J.D.G. and Nachtigal, J.C. 2003. Shortening of the juvenile period in the grapevine: a protocol for use in grape breeding. In: Congresso Latinoamericano de Viticultura y Enolgia, 9, 24 a 28 Nov. 2003, Santiago do Chile: Pontifícia Universidad Católica de Chile. p.30.

Christmann, M. 2005. Winemaking in the $21^{\text {st }}$ century. In: Congresso Latino-Americano de Viticultura e Enologia, 10, 07 a 11/11/2005, Bento Gonçalves, Anais... Bento Gonçalves: Embrapa Uva e Vinho. p.37-40.

Di Lorenzo, R. 2003. The world table grape production. In: Jornadas Gesco, 13, 3 to 8 
Feb. 2003, Montevideo: Faculdad Agronomia/INIA. p.219-228.

Huglin, P. and Julliard, B. 1964. Sur l'obtention de semis de vignes très vigoreux à mise à fruits rapide et ses répercutions sur l'amélioration génétique de la vigne. Annales de l'Amélioration des Plantes, Paris, 14:229-244.

Lima, J.C.de., Cripa, A., Garrido, L.da.R., Oliveira, P.R.D.de. and Camargo, U.A. 2002. Phenotypic evaluation and PCR-based markers for seedlessness studies in grape. In: International Conference on Grape Genetics and Breeding, 8, 26 a 31 Aug. 2002, Kecskemét, Hungary. Program... Kecskemét: Office International de la Vigne et du Vin. p.30.

\section{$\underline{\text { Tables }}$}

Table 1. Some new grape cultivars for wine, table grape, juice and raisin released after 1990 by several grape breeding programs around the World.

\begin{tabular}{|c|c|c|}
\hline Country/Institution & Purpose & Cultivars/Information \\
\hline \multirow{3}{*}{$\begin{array}{l}\text { United States } \\
\text { Agricultural Research Service- } \\
\text { ARS/USDA }\end{array}$} & Table grape & Sweet Scarlet; Autumn Royal \\
\hline & Raisin & Melissa; Summer Royal; Summer \\
\hline & Rootstock & 10-17A; 10-23B; 6-19B (http://www.ars.usda.gov) \\
\hline \multirow{2}{*}{$\begin{array}{l}\text { United States } \\
\text { Arkansas University }\end{array}$} & Table grape & Neptune; Jupiter \\
\hline & Juice & Sunbelt (http://www.aragriculture.org) \\
\hline $\begin{array}{l}\text { United States } \\
\text { University of California }\end{array}$ & Table grape & $\begin{array}{l}\text { Autumn King; Scarlet Royal } \\
\text { (http://fps.ucdavis.edu) }\end{array}$ \\
\hline \multirow{2}{*}{$\begin{array}{l}\text { United States } \\
\text { Cornell University }\end{array}$} & Wine & Geneva Red 7; Traminette, Chardonel \\
\hline & Table grape & Marquis (http://www.nysaes.cornell.edu) \\
\hline $\begin{array}{l}\text { South Africa } \\
\text { Agricultural research Center- } \\
\text { ARC }\end{array}$ & Table grape & $\begin{array}{l}\text { Regall Sedless; Sunred Seedless; La Rochelle; } \\
\text { Bonheur; Dauphine } \\
\text { (http://www.delecta.co.za/) } \\
\text { Ebony Star (http://www.arc.agric.za/) }\end{array}$ \\
\hline \multirow{3}{*}{$\begin{array}{l}\text { Australia } \\
\text { CSIRO Plant Industry }\end{array}$} & Wine & Tyrian; Cienna; Rubienne \\
\hline & Raisin & Sunmuscat \\
\hline & Table grape & Millennium Muscat (http://www.csiro.au) \\
\hline \multirow{2}{*}{$\begin{array}{l}\text { Israel } \\
\text { Volcani Center }\end{array}$} & Wine & Argaman (http://www.agri.gov.il/) \\
\hline & Table grape & $\begin{array}{l}\text { Black Finger; Camea; Mystery; Prime; Rocky } \\
\text { Seedless; Spring blush (http://www.anfic.com.au) }\end{array}$ \\
\hline $\begin{array}{l}\text { Germany } \\
\text { Institute for Grapevine Breeding } \\
\text { Geilweilerhof (IRZ) }\end{array}$ & Wine & $\begin{array}{l}\text { Regent; Reberger; Calandro; Phoenix; Orion; } \\
\text { Staufer; Sirius; Villaris; Felicia } \\
\text { (http://www.bafz.de) }\end{array}$ \\
\hline $\begin{array}{l}\text { Hungary } \\
\text { Research Institute Kecskemét }\end{array}$ & Table grape & $\begin{array}{l}\text { Sarolta, Eszter; Opus; Flora; Fanny; Angela } \\
\text { Acta Hort. 652:321-327 (2004) }\end{array}$ \\
\hline \multirow{3}{*}{$\begin{array}{l}\text { Brazil } \\
\text { Embrapa/National Research } \\
\text { Center for Grape and Wine }\end{array}$} & Wine & Moscato Embrapa; BRS Lorena \\
\hline & Juice & $\begin{array}{l}\text { BRS Rúbea; Concord Clone 30; Isabel Precoce; } \\
\text { BRS Cora }\end{array}$ \\
\hline & Table grape & $\begin{array}{l}\text { Dona Zilá; Tardia de Caxias; BRS Clara; BRS } \\
\text { Linda; BRS Morena } \\
\text { (http://www.cnpuv.embrapa.br) }\end{array}$ \\
\hline
\end{tabular}


